\title{
Cost and Return Analysis of Cricket Bats Manufacturing Industry in Kashmir Valley of India
}

\author{
Imtiyaz ul Haq, Bilal Ahmad Dar \\ Assistant Professor (Senior Scale, Stage-3), Department of Economics University of Kashmir, Srinagar - \\ 190006, J\&K, India. \\ Ph.D Scholar, Department of Economics, University of Kashmir, Srinagar, J\&K, India.
}

\begin{abstract}
Cricket Bats manufacturing industry is a very prominent segment of the sports goods industry in Kashmir valley. Cricket bats are manufactured from willow wood which is found in abundance in Kashmir valley owing to its peculiar climatic conditions. Although, this industry has got promising prospects to flourish due to huge demand-supply gap, yet its growth has remained, by and large, restricted to District Anantnag only. With this backdrop, the present study was conducted to actually examine the status and viability of this industry. A detailed cost and return analysis has been worked out for a sample of 20 percent constituting about 40 industrial units chosen through random sampling technique. After a thorough analysis, net return per rupee of investment ratio works out to be 1.60, meaning thereby that this industry is reaping abnormal profits. There is further evidence that the condition of increasing returns to scale prevails. However, our cost analysis suggests that raw material in the form of willow wood constitutes about 50 per cent of cost of production, hence imposing checks to its further expansion. Furthermore, about 80 per cent of the sample entrepreneurs in this activity were found in the working age population, having some level of educational qualifications, sole proprietorship with more than 10 years of experience.
\end{abstract}

Keywords: cricket bats, cost structure, Kashmir, profitability, returns to scale.

\section{Introduction}

One of the major wood based industries in the valley of Kashmir is cricket bats manufacturing industry. The origin of the industry in Kashmir is supposed to be from Sialkot Pakistan. The technical knowhow was imported from England. This trade flourished in those areas of Kashmir where raw material was substantially available. The cricket bat industry has an impressive reputation of making bats which are exported to other states of India. The cricket bats are mostly manufactured from Willow trees. In Kashmir the hub of this activity is Tehsil Bijbehara of District Anantnag, where about 200 units are registered with the District Industries Centre (DIC). The district comprises 6 tehsils viz Bijbehara, Pahalgam, Anantnag, Dooru, Shangus and Kokernag. It is not only the rice bowl of the valley but also rich in many small and cottage industries like handicraft, food processing, sports industry etc. Among six above mentioned tehsils, Bijbehara is the only tehsil where people are largely engaged with sports industry. The tehsil constitutes 40 villages with 1 community block. Each unit manufactures, on an average, about 12000 bats per annum. The cricket bat industry in Kashmir is already employing 10000 people and collectively exports nearly thousands of cricket bats every year.(Detailed Project Report, 2009)

\section{Objectives of the Study}

i. To study the socio-economic characteristics of the unit holders.

ii. To evaluate the profitability of the bat manufacturing enterprises.

iii. To estimate the output elasticities of capital and labour.

\section{Methodology and Data}

In order to evaluate the profitability of the Cricket Bat Industry, we have done cost and return analysis of this venture with the help of the data collected through field study. The study has been conducted in different villages of Tehsil Bijbehara of District Anantnag. These villages include Sangam, Halmullah, Sather, Pujteng, Mirzapora, Marhama, Punjpora, Bijbehara, Semthan, Gund, Thajwara, and Veer. Out of 195 cricket bat manufacturing units in different villages of tehsil Bijbehara, 40 units (about 20\%) were randomly selected. The information regarding production, employment, sales etc. and various other socio-economic variables has been collected with the help of an open-end questionnaire, which was framed strictly in accordance with the objectives outlined above. Furthermore, these units were sub-classified into small, medium and large categories, without using any conventional definition of classification, in order to make the analysis more scientific. A description of statistical methods used is given below. 


\title{
3.1 Cost and Return Analysis
}

$\mathrm{GR}=\mathrm{Q} \times \mathrm{P} ; \mathrm{NR}=\mathrm{GR}-\mathrm{TPC}$;

$\mathrm{TPC}=\mathrm{TFC}+\mathrm{TVC} ; \mathrm{NPM}=\mathrm{NR} \div \mathrm{GR} \times 100$

NR per Re. of investment (Benefit-Cost ratio $)=\mathrm{NR} \div \mathrm{TPC}$

Where GR = gross revenue, $\mathrm{Q}=$ quantity of output, $\mathrm{P}=$ price per unit of output, $\mathrm{NR}=$ net returns (profit); $\mathrm{TPC}=$ total production cost, $\mathrm{TFC}=$ total fixed cost, $\mathrm{TVC}=$ total variable cost, and $\mathrm{NPM}=$ Net profit margin .

\subsection{Cobb Douglas production function}

The Cobb-Douglas production function in its stochastic form is expressed as:

$$
\mathrm{Q}=\mathrm{AL}{ }^{\alpha} \mathrm{K}^{\beta} \mathrm{U}
$$

Where $\mathrm{Q}=$ Output; $\mathrm{L}=$ Labour input; $\mathrm{K}=$ Capital input; $\alpha$ and $\beta$ (constants) are output elasticities of labour and capital respectively and $\mathrm{U}$ is a random variable. In order to determine the efficiency of factor inputs in production, information on the specific contribution of input factors is necessary. With a view to evaluate the contribution of each specific input factor in combination with other factors, responsible for change in output level, the Cobb-Douglas production function has been used to estimate the effect of factor inputs such as labour and capital on the output. The general form of Cobb-Douglas production function in its estimation form can be written as:

$$
\log \mathrm{Q}=\log \mathrm{A}+\alpha \log \mathrm{L}+\beta \log \mathrm{K}+\log \mathrm{U}
$$

\section{Analysis and Results}

The study has been discussed under the following headings

i. Socio-economic and demographic profile.

ii. Cost and return analysis.

\subsection{Socio-economic and Demographic Profile}

The selected unit holders on the basis of age, education, gender and other characteristics were identified and are presented below.

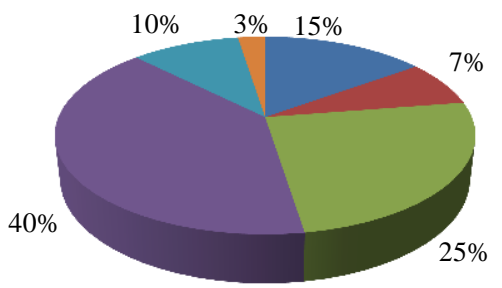

\author{
- Illiterate \\ - Elementary \\ - Secondary \\ - Higher secondary \\ - Graduate \\ - Post Graduate
}

Fig. 1 Education

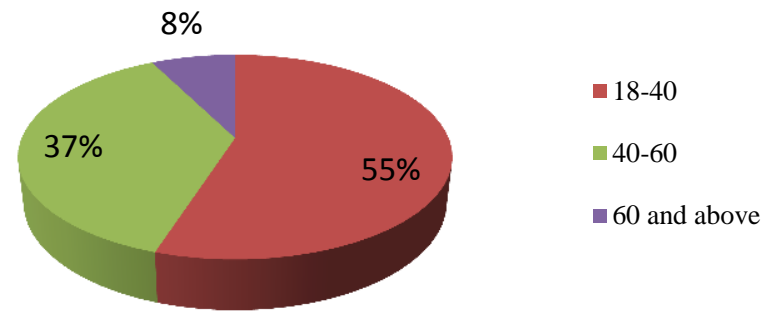

Fig. 2. Age

Source: Field Survey,2012

The data stratification suggests that out of the total unit holders surveyed majority of the unit holders i.e, 40 per cent were found to have higher secondary education, more than 12 per cent graduates and above, and only 15 per cent with no education. It is noteworthy to mention that no entrepreneur was found to have been trained professionally or possessed technical qualifications to manage the business. According to the information collected from the respondents more than 90 per cent belonged to the working age group of 18-60 years with no female participation, and almost 90 percent of them falling in the category of sole proprietorship. A survey of the respondents further revealed that 80 per cent of the unit holders were having the experience of 
running their business for more than 10 years, only 25 percent were dependant on the local banks for the financial resources and about 72 percent managed to have their own funds (Table 1A).

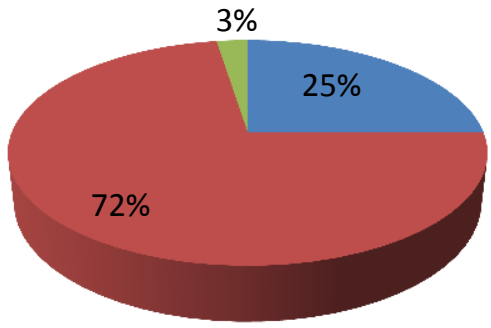

- Banks $\quad$ Own Capital $\quad$ Others

Fig. 3 Finance

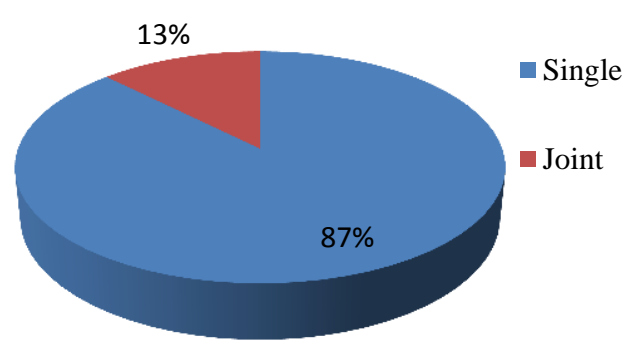

Fig. 4 Proprietorship

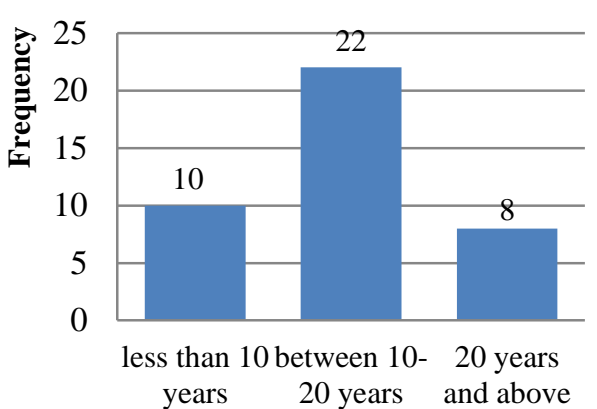

Fig. 5 Establishment Time

\subsection{Cost and Return Analysis}

Source: Field Survey,2012

In this section a detailed cost and return analysis technique has been employed to work out various components of production process to find out certain ratios as explained in the methodology section. Besides, Cobb-Douglas production function is employed to estimate the contribution of capital and labour to the level of output.

\subsubsection{Cost Structure}

The cost structure of the industry is discussed under two broad categories- fixed costs and variable costs. The different items of fixed costs are machinery, building, rental value, salary to top management staff, interest, taxes and insurance. The variable costs consist of expenditure on raw material (willow logs), wages, fuel, transport, repair and maintenance, other expenses like expenditure on packing, thread, grips, ragmal, stickers etc.

\subsubsection{Fixed costs}

i) Capital. Capital constitutes machinery and building in our study. In order to find out annual value of machinery and building consumed in the process of production, we have to make an assessment of life span of these assets. After deliberating with the respondents the life of these assets was estimated to be about 50 years. From the analysis of the data in Table 1, it was found that, on an average, annual capital consumption was highest in case of business with investment more than 40 lacs, accounting for Rs 0.30 lacs, while as it was found to be lowest in case of business with the investment less than Rs 20 lacs, accounting for Rs 0.11 lacs. For all the three type of unit holders, taken together, average annual capital consumption was calculated to be Rs 0.18 lacs. Capital cost component per unit of output (average cost) was found to be highest in case of large size investment unit holders i.e. Rs 2.1 and lowest in case of small investment unit holders i.e. Rs 1.17. While as it was found to be Rs 1.53 in case of business units with an investment between Rs 20-40 lacs. For all the three categories taken together it was found to be Rs. 1.50. 
Table 1: Capital cost component (category wise)

\begin{tabular}{|c|c|c|c|c|c|c|}
\hline $\begin{array}{c}\text { Size of investment } \\
\text { (Rs lacs) }\end{array}$ & 俤 & $\begin{array}{c}\text { Annual } \\
\text { Production } \\
\text { (Nos. lacs) }\end{array}$ & $\begin{array}{c}\text { Total value } \\
\text { of capital } \\
\text { Rs lacs }\end{array}$ & $\begin{array}{c}\text { Total annual } \\
\text { capital } \\
\text { consumption } \\
\text { Rs lacs }\end{array}$ & $\begin{array}{c}\text { Annual capital } \\
\text { consumption } \\
\text { (Average) } \\
\text { Rs lacs }\end{array}$ & $\begin{array}{c}\text { Capital cost } \\
\text { component } \\
\text { per bat/Rs }\end{array}$ \\
\hline $\mathbf{1}$ & $\mathbf{2}$ & $\mathbf{3}$ & $\mathbf{4}$ & $\mathbf{5 = 4 \div 5 0}$ & $\mathbf{6 = 5} \mathbf{2}$ & $\mathbf{7 = 5 \div 3}$ \\
\hline Below 20 & 14 & 1.40 & 82.1 & 1.642 & 0.11 & 1.17 \\
\hline $20-40$ & 22 & 2.86 & 220 & 4.40 & 0.30 & 1.53 \\
\hline 40 and above & 04 & 0.60 & 63 & 1.26 & $\mathbf{0 . 1 8}$ & $\mathbf{1 . 5 0}$ \\
\hline All the three & $\mathbf{4 0}$ & $\mathbf{4 . 8 6}$ & $\mathbf{3 6 5 . 1}$ & $\mathbf{7 . 3 0}$ & & \\
\hline
\end{tabular}

ii) Rental value. Rental value of the land is one of the important input costs in the cricket bat manufacturing industry. Rental value of land in case of the prospective unit holders was calculated on the basis of its opportunity cost i.e. next best alternative use foregone. We calculated rental value in terms of existing market value of land by taking into account savings rate of 8 percent per annum usually offered by the banks on the fixed deposit. During our field survey the average market value of land, found as Rs 20 lacs per kanal ${ }^{1}$, was multiplied by the total quantity of land held under bat manufacturing units by different class size investment business groups. The total rental value per year in different classes was obtained by applying 8 per cent rate of interest. Finally, in order to calculate the rental value per bat category wise, total rental values in each class was divided by the total annual production of bats. Different rental values in each class are shown in the Table 2 .

Rental value cost component per bat seems to vary inversely with the size of industrial units as is shown in the table. For all the three types of unit holders, taken together, rental value cost component per bat was found to be Rs 18.76. The rental value decreases with increase in size of investment because average production seems to increase with the increase in size of the industrial unit.

iii) Salary to management staff. Salary to management staff constitutes an important component of cost in the manufacturing of cricket bats. This component is included in the fixed cost category which is different from daily wages taken as variable cost component. From the data contained in the table it is clear that salary cost component in terms of per unit of output also varies inversely with the size of industry. On an average, salary cost component per unit of output works out to be Rs.13.82. However, it was observed during our field survey that the salaries offered to its employees in this industry remained uniform irrespective of the size of industrial undertaking.

Table 2: Rental value cost component (category wise)

\begin{tabular}{|c|c|c|c|c|c|}
\hline $\begin{array}{c}\text { Size of investment } \\
\text { (Rs lacs) }\end{array}$ & Frequency & $\begin{array}{c}\text { Annual } \\
\text { Production } \\
\text { (Nos.) } \\
\text { lac }\end{array}$ & $\begin{array}{c}\text { land under bat } \\
\text { industry } \\
\text { (kanals) }\end{array}$ & $\begin{array}{c}\text { Rental } \\
\text { value @ 8\% } \\
\text { per annum } \\
\text { lacs }\end{array}$ & $\begin{array}{l}\text { Rental value cost } \\
\text { component } \\
\text { per } \\
\text { bat/Rs }\end{array}$ \\
\hline $\mathbf{1}$ & $\mathbf{2}$ & $\mathbf{3}$ & $\mathbf{4}$ & $\mathbf{5}$ & $\mathbf{6 = 5} \div \mathbf{3}$ \\
\hline Below 20 & 14 & 1.40 & 18.50 & 29.60 & 21.14 \\
\hline $20-40$ & 22 & 2.86 & 32.50 & 52.00 & 18.18 \\
\hline 40 and above & 04 & 0.60 & 6.00 & 9.60 & 16.00 \\
\hline All the three & $\mathbf{4 0}$ & $\mathbf{4 . 8 6}$ & $\mathbf{5 7}$ & $\mathbf{9 1 . 2 0}$ & $\mathbf{1 8 . 7 6}$ \\
\hline
\end{tabular}

Source; Field Survey,2012

Table 3: Salary cost component (category wise)

\begin{tabular}{|c|c|c|c|c|c|c|}
\hline $\begin{array}{c}\text { Size of } \\
\text { investment } \\
\text { (Rs lacs) }\end{array}$ & Frequency & $\begin{array}{c}\text { Annual } \\
\text { production } \\
\text { (Nos.) lacs }\end{array}$ & $\begin{array}{c}\text { Managerial } \\
\text { staff (Nos.) }\end{array}$ & $\begin{array}{c}\text { Total } \\
\text { annual } \\
\text { salary } \\
\text { lacs }\end{array}$ & $\begin{array}{c}\text { Annual } \\
\text { salary } \\
\text { (Average) } \\
\text { lacs }\end{array}$ & $\begin{array}{c}\text { Salary cost } \\
\text { component } \\
\text { per bat } / \text { Rs }\end{array}$ \\
\hline $\mathbf{1}$ & $\mathbf{2}$ & $\mathbf{3}$ & $\mathbf{4}$ & $\mathbf{5}$ & $\mathbf{6 = 5} \div \mathbf{2}$ & $\mathbf{7 = 5} \div \mathbf{3}$ \\
\hline Below 20 & 14 & 1.40 & 28 & 23.76 & 1.68 & 16.80 \\
\hline $20-40$ & 22 & 2.86 & 44 & 36.96 & 1.68 & 12.92 \\
\hline 40 and above & 04 & 0.60 & 8 & 6.72 & 1.68 & 11.20 \\
\hline All the three & $\mathbf{4 0}$ & $\mathbf{4 . 8 6}$ & $\mathbf{8 0}$ & $\mathbf{6 7 . 2 4}$ & $\mathbf{1 . 6 8}$ & $\mathbf{1 3 . 8 2}$ \\
\hline
\end{tabular}

Source: Field Survey,2012

${ }^{1}$ The cost of the land per kanal is high because the land is located on either sides of the national highway. 
iv) Insurance. Cricket bat manufacturing units are subject to various types of risks, to protect against such risks, units are insured. Analysis of the surveyed units revealed that when all the three categories are taken together, average annual insurance amounted to be Rs 0.11 lacs. However, the insurance cost component per bat varies according to size of investment. It was observed highest in case of large size investment holders i.e. Rs 1.40 , followed by medium size investment unit holders and is lowest in case of small investment unit holders i.e. Re. 0.92. On the whole insurance cost component per unit of output was estimated as Re.0.92.

Table 4: Insurance cost component (category wise)

\begin{tabular}{|c|c|c|c|c|c|}
\hline $\begin{array}{c}\text { Size of } \\
\text { investment } \\
\text { (Rs lacs) }\end{array}$ & Frequency & $\begin{array}{c}\text { Annual } \\
\text { Production } \\
\text { (Nos.) }\end{array}$ & $\begin{array}{c}\text { Total annual } \\
\text { insurance (Rs } \\
\text { lacs) }\end{array}$ & $\begin{array}{c}\text { Annual } \\
\text { insurance } \\
\text { (Average) } \\
\text { (lacs) }\end{array}$ & $\begin{array}{c}\text { Insurance cost } \\
\text { component per } \\
\text { bat/ Rs }\end{array}$ \\
\hline $\mathbf{1}$ & $\mathbf{2}$ & $\mathbf{3}$ & $\mathbf{4}$ & $\mathbf{5 = 4 \div 2}$ & $\mathbf{6 = 4 \div 3}$ \\
\hline Below 20 & 14 & 1.40 & 1.30 & 0.09 & 0.92 \\
\hline $20-40$ & 22 & 2.86 & 2.50 & 0.11 & 0.87 \\
\hline 40 and above & 04 & 0.60 & 0.85 & 0.21 & $\mathbf{0 . 1 1}$ \\
\hline All the three & $\mathbf{4 0}$ & $\mathbf{4 . 8 6}$ & $\mathbf{4 . 6 5}$ & & $\mathbf{0 . 9 5}$ \\
\hline
\end{tabular}

Source: Field Survey,2012

Table 5: Other costs component (category wise)

\begin{tabular}{|c|c|c|c|c|c|}
\hline $\begin{array}{c}\text { Size of } \\
\text { investment } \\
\text { (Rs lacs) }\end{array}$ & Frequency & $\begin{array}{c}\text { Annual } \\
\text { Production } \\
\text { (Nos. lacs) }\end{array}$ & $\begin{array}{c}\text { Total annual } \\
\text { other costs Rs } \\
\text { lacs }\end{array}$ & $\begin{array}{c}\text { Annual } \\
\text { other cost } \\
\text { (Average) } \\
\text { Rs lacs }\end{array}$ & $\begin{array}{c}\text { Other cost } \\
\text { component per bat/ } \\
\text { Rs }\end{array}$ \\
\hline $\mathbf{1}$ & $\mathbf{2}$ & $\mathbf{3}$ & $\mathbf{4}$ & $\mathbf{5 = 4 \div 2}$ & $\mathbf{6 = 4 \div 3}$ \\
\hline Below 20 & 14 & 1.40 & 2.50 & 0.17 & 1.78 \\
\hline 20-40 & 22 & 2.86 & 3.70 & 0.16 & 1.29 \\
\hline All the three & 04 & 0.60 & 1.60 & 0.40 & 2.66 \\
\hline
\end{tabular}

Source: Field survey,2012

v) Other costs. The Other cost items like taxes and interest have been clubbed together and are shown in Table 5. For all the three categories of businesses taken together annual other costs, on an average, were calculated to be Rs 0.19 lacs. However, this component of the cost was observed highest in case of the large industrial enterprises with an establishment investment of more than 40 lacs, amounting to Rs 0.40 lacs. Other cost component per bat was found to be highest in case of industrial unit holders with an investment of more than Rs 40 lacs and lowest in case of business with an investment of between Rs 20-40 lacs, accounting for Rs.2.66 and Rs 1.29 respectively.

\subsubsection{Variable costs}

i) Raw material (willow) ${ }^{2}$ An important input without which bat industry is handicapped is willow. As we know, Cricket bats are mostly manufactured from willow. The table 6 shows that cost of raw material, on an average, for all the three categories was calculated to be Rs 12.88 lacs annually. Our analysis suggests that annual raw material consumption increases with the increase in the size of the industry which possibly suggests a no demand constrain condition. However, raw material cost component per bat tends to vary directly with the size of the industry among all the three categories. On an average for all the three categories together, raw material cost per unit of output works out to be Rs.106. The reason for increase in the cost per bat with the increase in the size of investment is that, because average annual raw material consumption increases with the size of investment. It appears that there is inverse relation between capital consumption efficiency and size of the business.

2. It includes cost of carrying the willow logs from primary producers to the industrial units. 
Table 6: Raw material cost component (Category wise)

\begin{tabular}{|c|l|c|c|c|c|}
\hline $\begin{array}{c}\text { Size of } \\
\text { investment } \\
\text { (Rs lacs) }\end{array}$ & 总 & $\begin{array}{c}\text { Annual } \\
\text { Production } \\
\text { (Nos. lacs) }\end{array}$ & $\begin{array}{c}\text { Total annual } \\
\text { raw material } \\
\text { consumption } \\
\text { Rs lacs }\end{array}$ & $\begin{array}{c}\text { Annual raw } \\
\text { material } \\
\text { consumption } \\
\text { (Average) } \\
\text { Rs lacs }\end{array}$ & $\begin{array}{c}\text { Raw material cost } \\
\text { component per } \\
\text { bat/Rs }\end{array}$ \\
\hline $\mathbf{1}$ & $\mathbf{2}$ & $\mathbf{3}$ & $\mathbf{4}$ & $\mathbf{5 = 4 \div 2}$ & $\mathbf{6 = 4 \div 3}$ \\
\hline Below 20 & 14 & 1.40 & 145.00 & 10.35 & 103.57 \\
\hline $20-40$ & 22 & 2.86 & 305.50 & 13.88 & 106.81 \\
\hline 40 and above & 04 & 0.60 & 65.00 & 16.25 & 108.33 \\
\hline All the three & $\mathbf{4 0}$ & $\mathbf{4 . 8 6}$ & $\mathbf{5 1 5 . 5 0}$ & $\mathbf{1 2 . 8 8}$ & $\mathbf{1 0 6 . 0 6}$ \\
\hline
\end{tabular}

Source: Field survey, 2012

ii) Human labour. Labour plays a dominant role in the cricket bat manufacturing industry. Human labour in the bat industry is employed on monthly basis and paid in cash in the form of wages. Our analysis shows that annual wages of unit holders increases with the increase in size of investment. Which is obvious because with more investments more employment opportunity is generated. However, on an average, for all the three type of units the annual average wage is about to Rs 3.36 lacs. It is clear from the above table that labor cost component per bat increases with the increase in size of investment. Labour cost component per bat is lowest in case of unit holders with investment less than Rs 20 lacs (smallest), while in case of medium and large unit holders labour cost component per bat is almost same i.e. Rs 28.11 and Rs 28.33 respectively. The reason for lowest labour cost in smaller units is that these units are employing the family labour along with hired labour. Further, these small size unit holders are able to keep close watch in their business affairs, which adds to their efficient management.

iii) Transport cost. Our field study revealed that cricket bats are mostly exported to Delhi, Jalhander, Meerut, Gujarat, Mumbai, and Karnataka etc. In order to export cricket bats to these States, an industry pays transportation cost. The above table shows that while annual transport cost varies directly, the transport cost per unit of output varies indirectly with size of the enterprise. In case of unit holders with investment more than Rs 40 lacs, annual transport cost was highest i.e. Rs 2.02 lacs and lowest in case of the business with investment less than Rs 20 lacs, accounting for Rs 1.43 lacs. On an average, for all the three categories, annual transport cost was worked out to be Rs 1.70

Table 7: Human labour cost component (Category wise)

\begin{tabular}{|c|c|c|c|c|c|c|c|c|c|}
\hline \multirow[b]{2}{*}{ 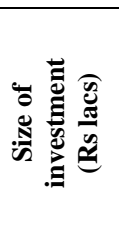 } & \multirow[b]{2}{*}{ 总 } & \multirow[b]{2}{*}{ 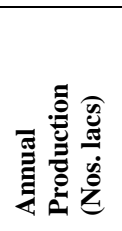 } & \multicolumn{4}{|c|}{ Employment } & \multirow[b]{2}{*}{ 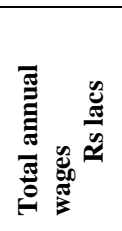 } & \multirow[b]{2}{*}{ 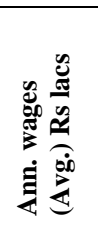 } & \multirow[b]{2}{*}{ 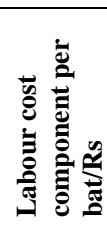 } \\
\hline & & & $\frac{\bar{d}}{\bar{\theta}}$ & 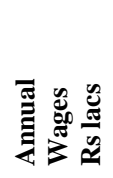 & 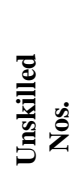 & 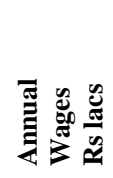 & & & \\
\hline 1 & 2 & 3 & 4 & 5 & 6 & 7 & $8=5+7$ & $9=8 \div 2$ & $10=8 \div 3$ \\
\hline Below 20 & 14 & 1.40 & 50 & 30 & 15 & 7.2 & 37.20 & 2.65 & 26.42 \\
\hline $20-40$ & 22 & 2.86 & 90 & 54 & 55 & 26.40 & 80.40 & 3.65 & 28.11 \\
\hline $\begin{array}{l}40 \text { and } \\
\text { above }\end{array}$ & 04 & 0.60 & 20 & 12 & 12 & 5.04 & 17.04 & 4.26 & 28.33 \\
\hline $\begin{array}{l}\text { All the } \\
\text { three }\end{array}$ & 40 & 4.86 & 160 & 96 & 66 & 38.64 & 134.64 & 3.36 & 27.70 \\
\hline
\end{tabular}

Table 8: Transport cost component (Category wise)

\begin{tabular}{|c|c|c|c|c|c|}
\hline $\begin{array}{c}\text { Size of } \\
\text { investment } \\
\text { (Rs lacs) }\end{array}$ & Frequency & $\begin{array}{c}\text { Annual } \\
\text { Production } \\
\text { (Nos. lacs) }\end{array}$ & $\begin{array}{c}\text { Annual } \\
\text { transport cost } \\
\text { (Rs lacs) }\end{array}$ & $\begin{array}{c}\text { Average } \\
\text { transport cost } \\
\text { per unit } \\
\text { (Rs lacs) }\end{array}$ & $\begin{array}{c}\text { Transport cost } \\
\text { component per } \\
\text { bat/Rs }\end{array}$ \\
\hline $\mathbf{1}$ & $\mathbf{2}$ & $\mathbf{3}$ & $\mathbf{4}$ & $\mathbf{5 = 4 \div 2}$ & $\mathbf{6 = 4 \div 3}$ \\
\hline Below 20 & 14 & 1.40 & 20.10 & 1.43 & 14.35 \\
\hline $20-40$ & 22 & 2.86 & 40.15 & 1.82 & 14.03 \\
\hline 40 and above & 04 & 0.60 & 8.10 & 2.02 & 13.50 \\
\hline All the three & $\mathbf{4 0}$ & $\mathbf{4 . 8 6}$ & $\mathbf{6 8 . 3 5}$ & $\mathbf{1 . 7 0}$ & $\mathbf{1 4 . 0 6}$ \\
\hline
\end{tabular}

Source: Field survey,2012 
lacs.. Transport cost component per bat stands at Rs 14.35, Rs 14.03 and Rs 13.50 for small, medium and large unit holders respectively. It was reported, as well as personally observed, from the field survey that large business units mostly had their own means of transport for export of their products because of which they could economise the transport costs.

iv). Power and fuel. For the functioning of cricket bat manufacturing industry, power and other fuels plays an important role. Fuel composition in our analysis includes consumption of power, diesel and petrol. Table 9 depicts that, on an average, energy cost increase with the increase in level of investment. In case of the unit holders with investment more than Rs 40 lacs, energy cost is highest, accounting for Rs 0.72 lacs annually, followed by the industrial activity with investment between Rs 20-40 lacs and is lowest in case of the business with investment below Rs 20 lacs, accounting for 0.6 lacs and Rs 0.48 lacs respectively. The table also shows that, per unit energy cost is almost same for all the three categories ranging between Rs 4.6 to Rs 4.8 with an average for all the three equal to Rs 4.6.

Table 9: Power and fuel cost component (category wise)

\begin{tabular}{|c|c|c|c|c|c|c|c|}
\hline $\begin{array}{c}\text { Size of } \\
\text { investment } \\
\text { (Rs lacs) }\end{array}$ & Frequency & $\begin{array}{c}\text { Annual } \\
\text { Production } \\
\text { (Nos. lacs) }\end{array}$ & $\begin{array}{c}\text { Power } \\
\text { charges } \\
\text { annually } \\
\text { Rs lacs }\end{array}$ & $\begin{array}{c}\text { Fuel } \\
\text { charges } \\
\text { annually } \\
\text { Rs lacs }\end{array}$ & $\begin{array}{c}\text { Total } \\
\text { energy } \\
\text { cost } \\
\text { Rs lacs }\end{array}$ & $\begin{array}{c}\text { Annual } \\
\text { energy cost } \\
\text { (Average) } \\
\text { Rs lacs }\end{array}$ & $\begin{array}{c}\text { Energy cost } \\
\text { component } \\
\text { per bat/Rs }\end{array}$ \\
\hline $\mathbf{1}$ & $\mathbf{2}$ & $\mathbf{3}$ & $\mathbf{4}$ & $\mathbf{5}$ & $\mathbf{6 = 4 + 5}$ & $\mathbf{7 = 6} \div \mathbf{2}$ & $\mathbf{8 = 6} \div \mathbf{3}$ \\
\hline Below 20 & 14 & 1.40 & 3.36 & 3.36 & 6.72 & 0.48 & 4.8 \\
\hline $20-40$ & 22 & 2.86 & 5.28 & 7.92 & 13.20 & 0.60 & 4.6 \\
\hline 40 and above & 04 & 0.60 & 0.96 & 1.92 & 2.88 & 0.72 & 4.8 \\
\hline All the three & $\mathbf{4 0}$ & $\mathbf{4 . 8 6}$ & $\mathbf{9 . 6 0}$ & $\mathbf{1 3 . 2 0}$ & $\mathbf{2 2 . 8}$ & $\mathbf{0 . 5 7}$ & $\mathbf{4 . 6}$ \\
\hline
\end{tabular}

v) Other costs. These costs include expenditure on grips, thread, ragmal, polish, and handles in our study. Table 10 gives a clear picture of these costs. The annual other costs, on an average, are calculated to be Rs 2.56 lacs for all the three categories, while as interms of per unit of output basis it amounts to Rs. 21. The analysis also shows that these costs tend to decrease with the large scale production. The reason being that the large investment unit holders directly purchases items like grip, thread, fevicol etc from the wholesalers at concessional prices.

vi) Repair and maintenance. These costs constitute almost insignificant proportion of the cost of production. The above table reveals that, repair and maintenance costs are highest in case of those industrial units whose investment is more than Rs 40 lacs, accounting for Rs 0.11 lacs and is lowest in case of those industrial units whose investment less than Rs 20 lacs, accounting for Rs 0.08 lac. On an average repair and maintenance cost works out to be Rs 0.09 lacs for all the three categories taken together. However, repair and maintenance cost component per bat is almost same for all the three categories.

Table 10: Other costs component (category wise)

\begin{tabular}{|c|c|c|c|c|c|}
\hline $\begin{array}{c}\text { Size of } \\
\text { investment } \\
\text { (Rs lacs) }\end{array}$ & Frequency & $\begin{array}{c}\text { Annual } \\
\text { Production } \\
\text { (Nos. lacs) }\end{array}$ & $\begin{array}{c}\text { Other } \\
\text { annual costs } \\
\text { Rs lacs }\end{array}$ & $\begin{array}{c}\text { Average } \\
\text { annual } \\
\text { other } \\
\text { costs per } \\
\text { unit Rs } \\
\text { lacs }\end{array}$ & $\begin{array}{l}\text { Other cost } \\
\text { component per } \\
\text { bat/Rs }\end{array}$ \\
\hline $\mathbf{1}$ & $\mathbf{2}$ & $\mathbf{3}$ & $\mathbf{4}$ & $\mathbf{5 = 4 \div 2}$ & $\mathbf{6 = 4 \div 3}$ \\
\hline Below 20 & 14 & 1.40 & 32.90 & 2.35 & 23.50 \\
\hline $20-40$ & 22 & 2.86 & 58.30 & 2.65 & 20.38 \\
\hline 40 and above & 04 & 0.60 & 11.20 & 2.80 & 18.66 \\
\hline Total & $\mathbf{4 0}$ & $\mathbf{4 . 8 6}$ & $\mathbf{1 0 2 . 4 0}$ & $\mathbf{2 . 5 6}$ & $\mathbf{2 1 . 0 6}$ \\
\hline
\end{tabular}

Source: Field survey,2012 
Table 11: Repair and maintenance cost component (Category wise)

\begin{tabular}{|c|c|c|c|c|c|}
\hline $\begin{array}{c}\text { Size of } \\
\text { investment } \\
\text { (Rs lacs) }\end{array}$ & Frequency & $\begin{array}{c}\text { Annual } \\
\text { Production } \\
\text { (Nos. lacs) }\end{array}$ & $\begin{array}{c}\text { Repairs and } \\
\text { maintenance } \\
\text { Rs lacs }\end{array}$ & $\begin{array}{c}\text { Average repair } \\
\text { and } \\
\text { maintenance } \\
\text { cost Rs lacs }\end{array}$ & $\begin{array}{c}\text { Repairs and } \\
\text { maintenance } \\
\text { Cost component } \\
\text { per bat/Rs }\end{array}$ \\
\hline 1 & $\mathbf{2}$ & $\mathbf{3}$ & 4 & $\mathbf{5 = 4} \div \mathbf{2}$ & $\mathbf{6 = 4 \div 3}$ \\
\hline Below 20 & 14 & 1.40 & 1.12 & 0.08 & 0.80 \\
\hline 20-40 & 22 & 2.86 & 2.20 & 0.10 & 0.76 \\
\hline 40 and above & 04 & 0.60 & 0.44 & 0.11 & 0.76 \\
\hline All the three & $\mathbf{4 0}$ & $\mathbf{4 . 8 6}$ & $\mathbf{3 . 7 6}$ & $\mathbf{0 . 0 9}$ & $\mathbf{0 . 7 7}$ \\
\hline
\end{tabular}

Source: Field survey,2012

\subsubsection{Cost Composition and Aggregation}

So for as the cost structure of cricket bat manufacturing industry is concerned, raw material is the most expensive input. On an average, raw material constitutes about 50 percent of the total cost. This cost component, however, is highest in case of large business unit holders i.e. 52.13 percent, followed by medium investment business units and is lowest i.e. 41.07 percent in case of small investment business units. Human labour cost component per bat is the second major input which on average accounts for 13.46 percent of the total cost. It is highest in case of the business with investment more than Rs 40 lacs, accounting for 13.66 percent and is lowest in case of the business unit holders with investment less than Rs 20 lacs, accounting for 12.33 percent. Other costs including expenditure on handles, grips, thread etc. is the third major input cost, constituting about 10 percent of the total cost on an average for all the three categories. This cost component is highest in case of small investment unit holders i.e. 10.90 percent, followed by medium investment unit holders and lowest in case of large investment unit holders i.e. 8.98 percent. Rental value enters the cost composition as the fourth major input. This cost constitutes 8.76 percent of the total cost. This cost component is highest in case of small investment unit holders i.e. 9.81 percent, followed by medium investment unit holders and lowest in case oflarge investment unit holders i.e. 7.7 percent.

Table 12 Cost Structure

\begin{tabular}{|c|c|c|c|c|c|c|c|c|c|c|c|c|c|c|c|}
\hline \multirow[b]{2}{*}{ 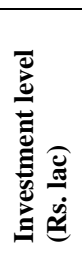 } & \multirow[b]{2}{*}{ 总 } & \multicolumn{6}{|c|}{ Fixed Costs (Rs.) } & \multicolumn{7}{|c|}{ Variable costs (Rs.) } & \multirow[b]{2}{*}{ 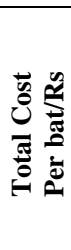 } \\
\hline & & 焉 & 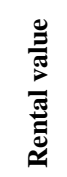 & 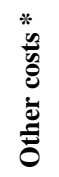 & 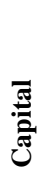 & 遏 & 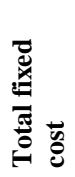 & 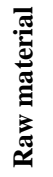 & 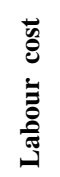 & 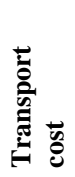 & 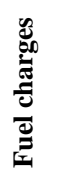 & 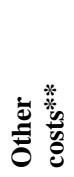 & 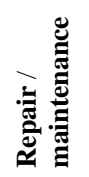 & 嵒 & \\
\hline $\begin{array}{l}\text { Below } \\
20\end{array}$ & 14 & $\begin{array}{l}\widehat{\hat{D}} \\
\stackrel{5}{0} \\
\stackrel{0}{0} \\
\stackrel{\Xi}{0}\end{array}$ & 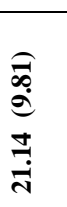 & 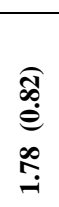 & 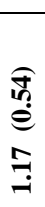 & $\begin{array}{l}\widehat{T} \\
\text { 仓े } \\
\hat{\delta}\end{array}$ & 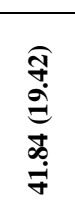 & 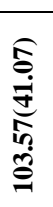 & & 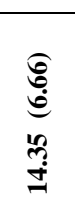 & 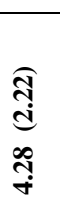 & 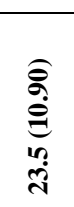 & $\begin{array}{l}\text { 尺̂. } \\
\stackrel{0}{\Theta} \\
\infty \\
\stackrel{0}{0}\end{array}$ & 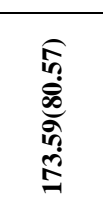 & 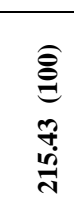 \\
\hline $\begin{array}{l}20- \\
40\end{array}$ & 22 & 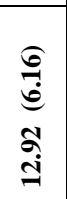 & $\begin{array}{l}\text { Ê } \\
\dot{\infty} \\
\infty \\
\infty \\
\dot{\infty}\end{array}$ & $\begin{array}{l}\widehat{\widehat{G}} \\
\stackrel{\oplus}{9} \\
\stackrel{9}{9}\end{array}$ & 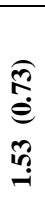 & $\begin{array}{l}\widehat{F} \\
\dot{e} \\
\widehat{\infty} \\
\dot{0}\end{array}$ & 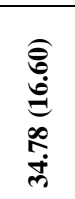 & 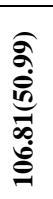 & 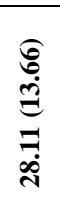 & 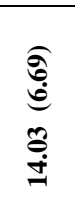 & $\begin{array}{l}\underset{\dot{i}}{\mathbf{d}} \\
\dot{+}\end{array}$ & 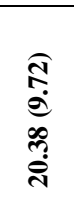 & $\begin{array}{l}\hat{\sigma} \\
\stackrel{0}{0} \\
\stackrel{0}{0} \\
\stackrel{0}{0}\end{array}$ & 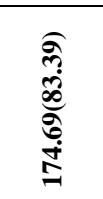 & 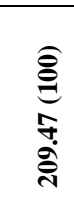 \\
\hline $\begin{array}{l}40 \& \\
\text { above }\end{array}$ & 04 & 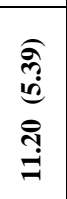 & 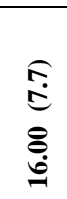 & 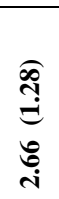 & $\begin{array}{l}\widehat{\widehat{\sigma}} \\
\vec{i} \\
\vec{i}\end{array}$ & $\begin{array}{l}\text { 芯 } \\
\stackrel{\Theta}{8} \\
\stackrel{9}{9}\end{array}$ & 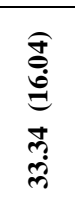 & 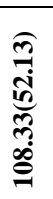 & 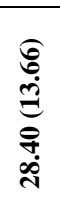 & 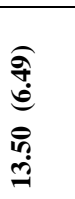 & $\begin{array}{l}\stackrel{\vec{m}}{d} \\
\stackrel{\infty}{d} \\
\stackrel{+}{+}\end{array}$ & 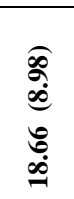 & $\begin{array}{l}\stackrel{0}{0} \\
\stackrel{3}{8} \\
\stackrel{0}{0} \\
\stackrel{0}{0}\end{array}$ & 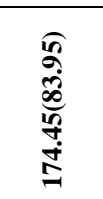 & $\begin{array}{l}\widehat{\widehat{\theta}} \\
\text { જે } \\
\hat{\tilde{े}}\end{array}$ \\
\hline $\begin{array}{l}\text { Avera } \\
\text { ge }\end{array}$ & 40 & 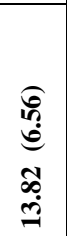 & 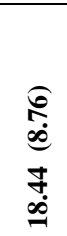 & 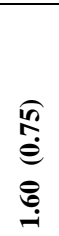 & 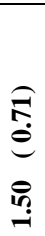 & 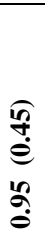 & 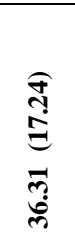 & 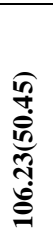 & 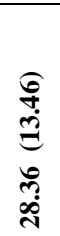 & 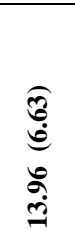 & $\begin{array}{l}\stackrel{3}{\mathfrak{d}} \\
\text { i } \\
\text { f }\end{array}$ & 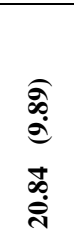 & 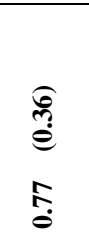 & 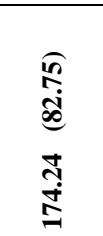 & 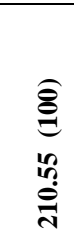 \\
\hline
\end{tabular}

Source: Calculated from tables 1 to 11. Figure in the parentheses reflect the percentage shares of inputs 
Transport cost component per bat is the fifth rank input of the cricket bat manufacturing industry which, on an average, accounts for about 7 percent of the total cost. The share of this cost component per bat was found to be almost same in all the three types of enterprises. Annual salary cost component occupies the sixth rank in the cost structure constituting about 6 percent of the total cost. This cost component stood highest in case of small investment unit holders i.e. 7.79 per cent followed by medium investment unit holders and lowest in case of large investment unit holders i.e. 5.37 percent. Cost of capital consumption, insurance, other costs, repair and maintenance appear to be less than 1 per cent in each respective category.

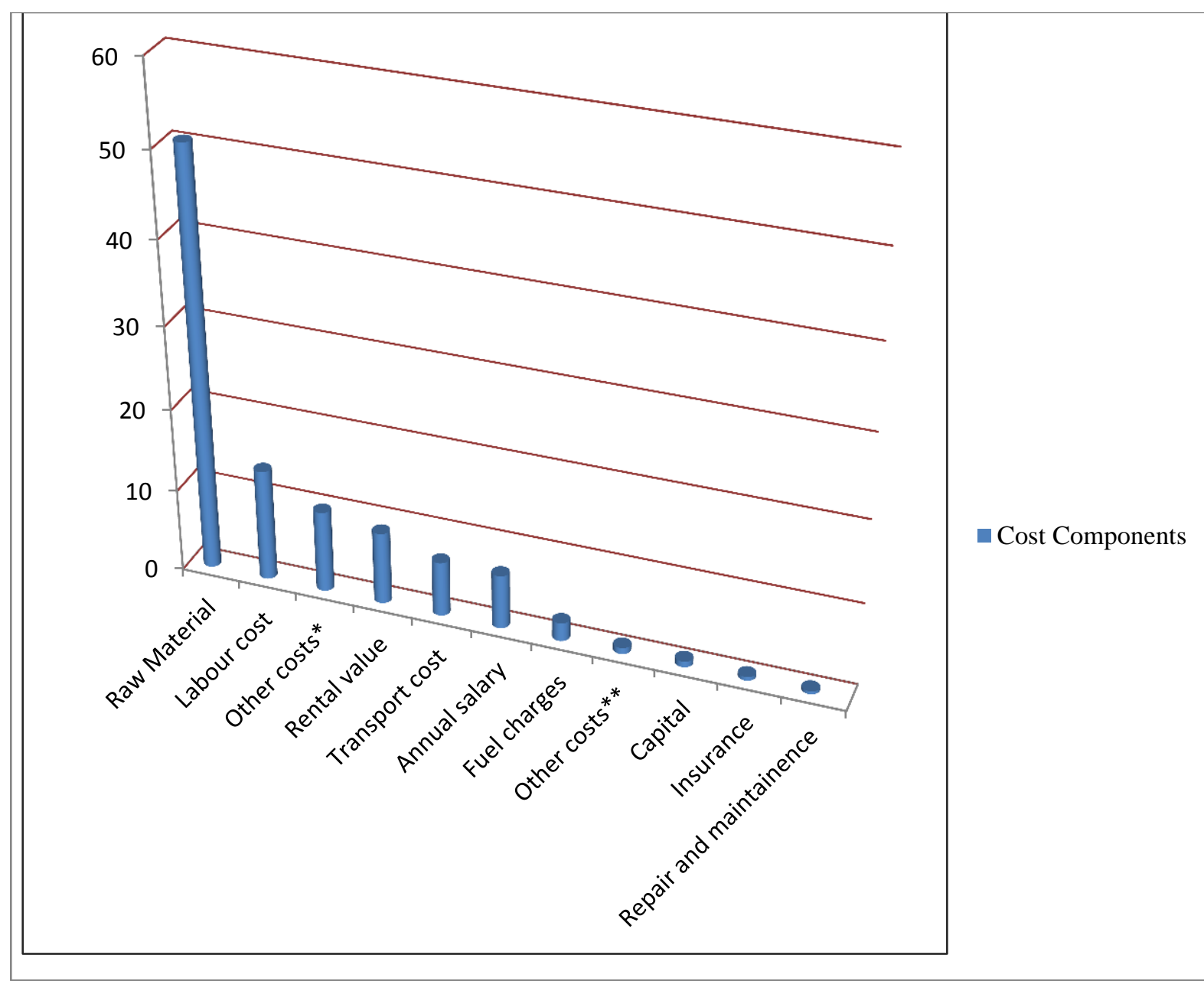

Source: Table 12

Fig.6 Cost Structure (Percentage share of inputs)

* include expenses on handles, grips, polish etc. **include interests and taxes

In order to work out the total cost per unit of output (per bat) all the fixed and variable cost components have been clubbed together. By clubbing them total expenditure per bat has been worked out which is shown in the table 12. As is clear from the data in table that average cost decreases with the increase in the level of investment. It is highest in case of small investment unit holders and lowest in case of large investment unit holders. The above analysis gives an indication that cricket bat manufacturing industry is subject to increasing returns to scale

\subsubsection{Returns to Investment}

An assessment of the returns from the sale of cricket bats was made on the basis of unit selling price. Since the products offered by these manufacturing units are generally of different price ranges, an average price of Rs. 550 was chosen after deliberating with the respondent unit holders. Based on this price the gross returns, on an average, in each of three classes of industries varied significantly showing a rising trend as the size of plant and machinery increased. Conversely, total production costs first seem to increase from small to medium investment class industry and then decline substantially in case of large class industries. Finally, as our estimates suggest the average total cost (per unit of output) continuously shows a declining tendency with the increase in the size of industry and the level of output. These findings are suggestive of the fact that cricket bat industry is 
subject to economies of scale. So for as the returns are concerned, the analysis suggests that net returns per unit of output have a tendency to increase with the level of investment, so that larger business holdings seem to earn higher profits.

\section{Table 13: Calculation of gross and net returns}

\begin{tabular}{|c|c|c|c|c|c|c|c|c|}
\hline 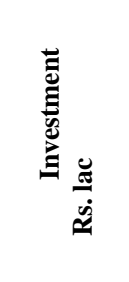 & 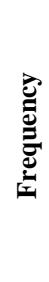 & 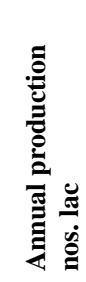 & 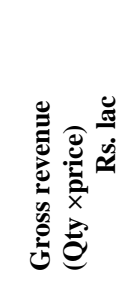 & 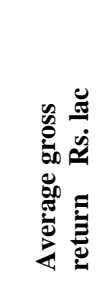 & 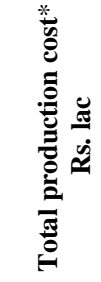 & 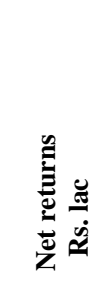 & 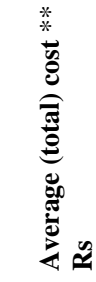 & 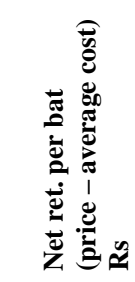 \\
\hline 1 & 2 & 3 & 4 & $5=4 \div 2$ & 6 & $7=4-6$ & 8 & 9 \\
\hline Below -20 & 14 & 1.40 & 770.00 & 55.00 & 301.84 & 468.60 & 215.43 & 334.57 \\
\hline $20-40$ & 22 & 2.86 & 1573.00 & 71.50 & 599.34 & 973.66 & 209.47 & 340.53 \\
\hline $\begin{array}{l}40 \text { and } \\
\text { above }\end{array}$ & 04 & 0.60 & 330.00 & 82.50 & 124.69 & 205.31 & 207.79 & 342.20 \\
\hline $\begin{array}{l}\text { All the } \\
\text { three }\end{array}$ & 40 & 4.86 & 2673.00 & 208.50 & 1025.84 & 1647.16 & 210.55 & 339.45 \\
\hline
\end{tabular}

*Calculated from Table Nos 1 to $11 \quad * *$ Refer to table 12

In terms of returns per rupee of investment, the gross returns vary between Rs 2.55 to Rs 2.64 among three categories, which on average is calculated as Rs 2.60 for all the three categories. Gross returns per rupee of investment is highest in case of large investment unit holders, accounting for Rs. 2.64, followed by medium size investment unit holders and is lowest in case of small investment unit holders i.e. Rs 2.55. Net returns per rupee of investment, on an average, are calculated to amount Rs 1.60 for all the three categories. It is highest in case of large investment unit holders i.e. Rs 1.64, followed by medium size investment unit holders and is lowest in case of small investment unit holders, accounting for Rs 1.55. An average value of 0.61 obtained for net profit margin signifies a very high degree of short-term profitability. (Table 14)

The estimation of production function of a Cobb-Douglas form, for cricket bat manufacturing industry on the basis of cross sectional data concerning a random sample of 40 units revealed the following equation:

$$
\begin{gathered}
\log \mathrm{Q}=0.3992+0.9752 \log \mathrm{L}+0.3442 \log \mathrm{K} \quad \mathrm{R}^{2}=0.64 \\
\operatorname{Se}(\hat{\alpha})=0.1828 \operatorname{Se}(\hat{\beta})=0.1319 \\
\text { Or, } \mathrm{Q}=\mathrm{A}(\mathrm{L})^{0.9752}(\mathrm{~K})^{0.3424} \quad \text { where, } \mathrm{A}=\mathrm{e}^{0.3992}
\end{gathered}
$$

From the above estimated results, it is observed that the output elasticities of labor and capital are 0.9752 and 0.3424 respectively. In other words, holding the capital input constant, a one percent increase in labor input leads on the average to about 0.97 percent increase in output. Similarly, holding the labor input constant, a one percent increase in capital leads on the average to about 0.34 percent increase in output. From the statistical view point, the estimated model fits the data well, the $\mathrm{R}^{2}$ - value of 0.64 means that about 64 percent of the variation in the(log of ) output is explained by the(logs of) labor and capital. Adding the two output elasticities, we obtain a value of 1.3176 , indicating a condition of increasing returns to scale. On the basis of estimated standard errors the elasticity of output with respect to labour and capital appears statistically significant. Thus, we can conclude that cricket bat manufacturing industry is subject to increasing returns to scale i.e. with the increase in the size of investment average cost of production declines. 
Table 14: Calculation of return on capital

\begin{tabular}{|c|c|c|c|c|c|c|}
\hline 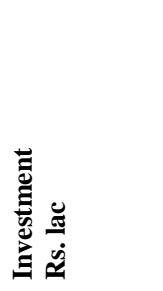 & 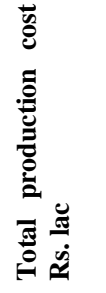 & 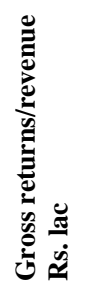 & 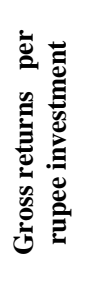 & 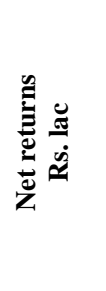 & 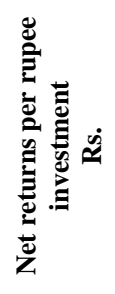 & 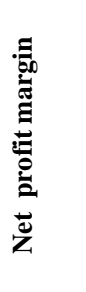 \\
\hline 1 & 2 & 3 & $4=3 \div 2$ & $5=3-2$ & $6=5 \div 2$ & $7=5 \div 3$ \\
\hline Below 20 & 301.84 & 770.00 & 2.55 & 468.16 & 1.55 & 0.60 \\
\hline $20-40$ & 599.38 & 1573.00 & 2.62 & 973.62 & 1.62 & 0.61 \\
\hline $40 \&$ above & 124.69 & 330.00 & 2.64 & 205.31 & 1.64 & 0.82 \\
\hline All the three & 1025.84 & 2673.00 & 2.60 & 1647.16 & 1.60 & 0.61 \\
\hline
\end{tabular}

\section{Summary and Concluding Remarks}

To sum up following observations are made:

i. The analysis shows that variable costs constitute more than 80 percent and fixed costs less than 20 percent of the total Production cost.

ii. The dominant input cost in all the three investment unit holders is raw material that constitutes more than half of the total cost, followed by labour and other costs including handle, grip, thread etc, accounting for about 14 percent and 10 percent respectively.

iii Net returns increase with the increase in the size of industry. The study also shows that small investment unit holders are least profitable because of higher cost of production per unit of output in terms of annual salary, rental value and other costs in the fixed cost category. Contrarily, small unit holders account for relatively lower variable costs but this advantage is more than offset by their relatively higher fixed costs.

iv. Net returns per rupee of investment vary between 1.55 and 1.64 among all the three categories, with an average value of 1.60 , and an average net profit margin ratio of about 0.60 .

The forgoing analysis suggests that cricket bat manufacturing industry has the potential to absorb the local educated youth and can act as a nursery for the development of entrepreneurial talent in the valley as a whole, since elasticity of output with respect to labour is very high the possibility of gainful employment seems to be very bright. This industry is highly profitable with a tendency to exhibit increasing returns to scale coupled with a very vast market leaving the industry virtually with no demand constraint. However, on the supply side the main obstacle seems to be the raw material, especially the willow logs, which is a very expensive and dominant input constituting about half of the cost of production. To remove this impediment role of the government in ensuring a strong supply side response through appropriate policy and incentives to create a suitable investment climate is very crucial. Launching pilot projects for growing willows, especially high quality English willows, along with imported technical knowhow can help this industry to become competitive at global level and penetrate the international markets.

\section{References}

[1] Anonymous, Diagnostic Study Report of Cricket Bat Manufacturing Cluster, District Industries Centre Anantnag (2010) J\&K Government.

[2] Anonymous, Detailed Project Report of Common Facility Centre, Directorate of Industries and Commerce (2009), Government of $\mathrm{J} \& \mathrm{~K}$

[3] A. Marshall, Elements of Economics of Industry (Macmillan \& Co. London, 1958 edition).

[4] C.E. Pratten, Economics of Scale in Manufacturing Industries(D.A.E. Occasional Paper No. 28, Cambridge University Press, Cambridge, 1971)

[5] D. Mueller, Profits in the Long-run (Cambridge University Press, 1986)

[6] D. Needham, Economic Analysis and Industrial Structure (Holt, Rinehart and Winston, New York, 1969)

[7] Damodar, N Gujrati, Basic Econometrics (Tata McGraw Hill Education Private Limited, New Delhi, 2012)

[8] E, Penrose, The Theory of the Growth of the Firm (Blackwell, Oxford, 1959)

[9] G. Whttington, The Prediction of Profitability ( Deptt. of Applied EconomicsCambridge University, Occasional Paper No. 22, Cambridge University Press, Cambridge, 1976.Francisco, 1973)

[10] G.C. Philippatos, Financial Analysis: Theory and Technique (Holden \& Day Inc., San G.J. Stigler, the Organization of Industries, R.D. Irwin, Homewood, 1968)

[11] H. Speight, Economics and Industrial Efficiency (Macmillan \& Co., London, 1970) 
[12] Hay and D. G. Morris, Industrial Economics: Theory and Evidence (Oxford University Press, London, 1979)

[13] Hay and D. G. Morris, Industrial Economics and Organization: Theory and Evidence (Oxford University Press, London, 1991)

[14] J. Tirole, The theory of Industrial Organization (The MIT Press, 1988)

[15] G.M.K Madnani Introduction to Econometrics- Principles and Application (Oxford \& IBH Publishing Co.. New Delhi 2009)

[16] R.R. Barthwal, Industrial Economics (New Age International Publishers, New Delhi, 2007)

[18] S. Martin, Advanced Industrial Economics (Oxford , Blackwell, 1993)

[19] S. Martin, Advanced Industrial Economics: Economic Analysis and Public Policy (London, Macmillan Pub. Co., 1989)

[20] United Nations Industrial Development Organization, Guide to Practical Project Appraisal: Social Benefit-Cost Analysis in Developing Countries (Oxford \& IBH Publishing Co.1978)

[21] W.G. Shephered, The Economics of Industrial Organization (Prentice Hall Inc., Englewood Cliffs, 1979)

\section{Appendix}

Table 1A: Socio-economic Profile of Unit Holders

\begin{tabular}{|c|c|c|c|}
\hline S.No & Profile & Frequency & Percentage \\
\hline 1 & Education & & \\
\hline $\mathrm{a}$ & Illiterate & 06 & 15.0 \\
\hline $\mathrm{b}$ & Primary & 03 & 7.50 \\
\hline $\mathrm{c}$ & Secondary & 10 & 25.00 \\
\hline $\mathrm{d}$ & Higher Secondary & 16 & 40.00 \\
\hline $\mathrm{e}$ & Graduate & 04 & 10.00 \\
\hline $\mathrm{f}$ & Post Graduate & 01 & 2.50 \\
\hline \multirow[t]{26}{*}{$\mathrm{g}$} & Professional & 0 & 0.00 \\
\hline & Total & 40 & 100 \\
\hline & Age(Years) & & \\
\hline & $18-40$ & 22 & 55.00 \\
\hline & $40-60$ & 15 & 37.50 \\
\hline & 60 and above & 03 & 7.50 \\
\hline & Gender(Male) & & \\
\hline & $18-40$ & 22 & 55.00 \\
\hline & $40-60$ & 15 & 37.50 \\
\hline & 60 and above & 03 & 7.50 \\
\hline & Total & 40 & \\
\hline & $18-40$ & 0 & 0 \\
\hline & $40-60$ & 0 & 0 \\
\hline & 60 and above & 0 & 0 \\
\hline & Proprietorship & & \\
\hline & Single & 35 & 87.5 \\
\hline & Joint & 05 & 12.5 \\
\hline & Leased & 0 & 0.00 \\
\hline & Financial Sources & & \\
\hline & Banks/Financial Institutions & 10 & 25 \\
\hline & Own Capital & 29 & 70 \\
\hline & Other & 01 & 05 \\
\hline & Establishment Time & & \\
\hline & Less than 10 Years & 10 & 25 \\
\hline & 10-20 Years & 22 & 55 \\
\hline & Above 20 Years & 08 & 20 \\
\hline
\end{tabular}

Source: Field Survey, 2012 